International Journal of Case Reports
(ISSN:2572-8776)

\title{
The diagnostic conundrum posed by Hypereosinophilia with a foot drop: A Case Report
}

\author{
Jonathan Moriarty ${ }^{1}$, Natassja Moriarty ${ }^{1}$, Anthony Macheta ${ }^{2}$, Fiona Wood ${ }^{3}$ \\ ${ }^{1}$ Department of Medicine, Department of Furness General Hospital \\ ${ }^{2}$ Department of Haematology, Furness General Hospital \\ ${ }^{3}$ Department of Rheumatology, Furness General Hospital
}

\begin{abstract}
We present a case of an 81-year-old asthmatic female with a left foot drop and an incidental finding of hypereosinophilia with an initial differential diagnosis of Eosinophilic Granulomatosis with Polyangiitis (EGPA). However, after extensive investigations, all causes of hypereosinophilia were excluded and the left foot drop was secondary to a radiculopathy. This led to a diagnosis of Idiopathic Hypereosinophilic Syndrome (IHES), a diagnosis of exclusion. This is the first case report where hypereosinophilia and a left foot drop where unrelated conditions occurring simultaneously thus posing a diagnostic dilemma. Therefore, this case report aims to highlight the importance of a systematic approach in the investigation of hypereosinophilia, to ascertain the cause and to rule out organ damage as this will affect the management and the outcome.
\end{abstract}

*Correspondence to Author:

Natassja Moriarty , Furness General Hospital, Dalton Lane, Barrow-in-Furness, LA14 4LF

How to cite this article:

Jonathan Moriarty, Natassja Moriarty, Anthony Macheta, Fiona Wood. The diagnostic conundrum posed by Hypereosinophilia with a foot drop: A Case Report. International Journal of Case Reports, 2020 $4: 136$.

Keywords: Idiopathic Hypereosinophilic syndrome, Hypereosinophilia, Eosinophilic Granulomatosis with Polyangiitis, case report

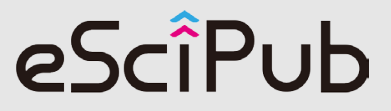

eSciPub LLC, Houston, TX USA. Website: http://escipub.com/ 


\section{Introduction}

An 81-year-old female with longstanding back pain presented with a 3-day history of a left foot drop and an incidental finding of an eosinophilia of $19.9 \times 10 / L 9(0.05-0.5 \times 10 / L$ 9). Significant past medical history included well-controlled asthma (diagnosed 30 years ago), oesophageal stricture with symptoms of dysphagia (20102012), and a mild eosinophilia ( $\left.1.6 \times 10^{9} / \mathrm{L}\right)$ dating back to 2014. There was nothing else in the history to suggest a secondary cause of her eosinophilia. She does not smoke or drink alcohol. Her family history was not significant for any medical conditions. She was afebrile and normotensive on admission. Significant examination findings included an absent ankle reflex and a reduced power of $1 / 5$ to the muscle groups of the left foot. There was no accompanying sensory deficit. The rest of the systemic examination was normal. Results of the relevant investigations to ascertain the cause of the Hypereosinophilia are summarised in the Table 1. Based on the results of the investigations, the patient was diagnosed as having Idiopathic Hypereosinophilic Syndrome, with an incidental L5-S2 radiculopathy. She was started on Prednisolone $40 \mathrm{mg}$ once daily. The results of her treatment are summarised in Table 2. Additionally, she received physiotherapy and orthotics for the foot drop. She remains well and is being followed up in the Haematology outpatient clinic where currently she is on alternative day dosing of her steroid.

\section{Discussion}

Hypereosinophilic syndrome (HES) is a term that encompasses a heterogeneous group of conditions characterized by hyperoesinophilia (eosinophils $>1.5 \times 10^{9} / \mathrm{L}$ ) for $>6$ months duration with organ damage 1 . 'Idiopathic HES' (IHES) is set aside for those with an undetermined aetiology despite extensive investigations 2. The true prevalence is unknown as it is a rare occurrence but is estimated to be 0.036 per 100,000 persons ${ }^{1}$. It most commonly occurs in ages $20-50$ years old, but it may also present at the extremes of age ${ }^{1,2}$. The underlying cause of the condition remains inconclusive, but it is believed to be due to overproduction of eosinophilipoietic cytokines or defects in suppressive regulation of eosinophils ${ }^{3}$. This is the first case report where a foot drop with simultaneous hypereosinophilia were unrelated conditions, thus stressing the importance of proper diagnostic evaluation of a raised eosinophil count. Hypereosinophilic conditions can be classified as haematologic (clonal, primary) when there is a lymphoid/myeloid neoplasm with rearrangement of platelet-derived growth factor receptor alpha (PDGFRA), platelet-derived growth factor receptor beta (PDGFRB), or fibroblast growth factor receptor 1 (FGFR1) genes ${ }^{4}$. These genes play a role in cellular proliferation and differentiation. Alternatively, a non-haematologic (secondary, reactive) classification is assigned if the hypereosinophilia is driven by an inflammatory process (due to overproduction of eosinophilopoeitic cytokines, especially interleukin 5$)^{4}$. A few examples include parasites, adverse drug reactions, EGPA, solid malignancies ${ }^{1,4}$. In the context of this case, Eosinophilic Granulomatosis with Polyangiitis (EGPA) was an important differential on the spectrum of HES- related diseases. EGPA is a necrotizing vasculitis of small -medium blood vessels characterized by eosinophilia and asthma ${ }^{5}$. It is the rarest of the anti-neutrophil cytoplasmic antibody (ANCA) - associated vasculitides (1-3 cases per million ${ }^{5}$ ) with serious outcomes and requires immunosuppression. Diagnosis of EGPA requires the fulfilment of 4 out of 6 of the American College of Rheumatology Classification ${ }^{6} .2$ out of 6 of the criteria were immediately apparent in the patient on admission: asthma and peripheral eosinophilia. However, it was subsequently ruled out along with other primary and secondary causes of eosinophilia, following further diagnostic evaluation. As previously stated, IHES is a diagnosis of exclusion. Its definition contains a remnant of the original diagnostic criteria proposed by Chusid et al in 1975: a duration of $>6$ months ${ }^{4}$. With the advent of more modern investigations to expeditiously assess and guide treatment of eosinophilia to avert or diminish organ damage, duration of $>6$ months is no longer a necessary requirement for 
diagnosis ${ }^{1}$. Interestingly, a retrospective look at $10 \%$ with an otherwise normal blood count, daour patient showed a mild eosinophilia of 1.6 x ting back to 2014 .

Table 1 showing the relevant investigations done throughout admission to ascertain the aetiology of the hypereosinophilia.

\begin{tabular}{|c|c|}
\hline Blood Investigations & Results \\
\hline Full blood count & $\begin{array}{l}\text { Haemoglobin } 108 \mathrm{~g} / \mathrm{L}(115-165), \text { MCV } 82.2 \mathrm{fL}(77-101) \text {, White Blood Cells } 39.8 \times 10^{9} / \mathrm{L} \\
(4-10), \text { Neutrophils } 15 \times 10^{9} / \mathrm{L}(2-7.5), \text { Lymphocytes } 3.2(1-3), \text { Eosinophil } 19.9 \times 10^{9} / \mathrm{L} \\
(0.02-0.5) \text {, Platelet } 385 \times 10^{9} / \mathrm{L}(150-400)\end{array}$ \\
\hline Vitamin B12 & $1001 \mathrm{ng} / \mathrm{L}(>203)$ \\
\hline Folate & $16 \mathrm{mcg} / \mathrm{L}(>4)$ \\
\hline Ferritin & $12 \mathrm{mcg} / \mathrm{L}(11-307)$ \\
\hline Thyroid function test & Normal \\
\hline Blood film & Eosinophilia with hyper-segmented neutrophils \\
\hline Blood culture & No growth after 5 days \\
\hline ANCA/ANCA ELISA & Negative \\
\hline $\begin{array}{l}\text { Anti-MPO and Anti-Proteinase } 3 \text { anti- } \\
\text { bodies }\end{array}$ & Negative \\
\hline ANA screen & Negative \\
\hline ENA screen & Negative \\
\hline Protein Electrophoresis & $\begin{array}{l}\text { IgG } 19.6 \mathrm{~g} / \mathrm{L}(6-16), \operatorname{lgM} 1.25 \mathrm{~g} / \mathrm{L}(0.5-2), \lg A 0.92 \mathrm{~g} / \mathrm{L}(0.8-4), \text { Total protein } 69 \mathrm{~g} / \mathrm{L}(60- \\
\text { 80), Paraprotein: No paraprotein detected }\end{array}$ \\
\hline Other Investigations & Results \\
\hline Faecal ova, cysts and parasites & Negative \\
\hline Urinalysis & Negative for eosinophiluria \\
\hline Nerve Conduction Studies & $\begin{array}{l}\text { Evidence of L5/ S2 radiculopathy. No evidence of peripheral neuropathy or mononeu- } \\
\text { ritis multiplex. Incidental Fibrillation at left iliopsoas suggesting myositis. }\end{array}$ \\
\hline Bone marrow biopsy & $\begin{array}{l}\text { Cytogenetics: No FIP1L1-PDGFRA fusion gene rearrangement. Normal female karyo- } \\
\text { type. No clonal abnormalities. Morphology: The bone marrow is cellular with active } \\
\text { trilineage haematopoiesis. This shows sequential maturation. Eosinophils and their } \\
\text { precursors are increased. Megakaryocytes are increased with occasional large forms } \\
\text { though clustering is not a feature. Molecular: No evidence of Val617 JAK2 or CALR } \\
\text { exon } 9 \text { mutation (markers of myeloproliferative neoplasms). Flow cytometry: No abnor- } \\
\text { mal phenotype nor aberrant expression found on cell markers. }\end{array}$ \\
\hline Pulmonary Function Test & Normal \\
\hline Echocardiogram & Ejection fraction $66 \%$, nil abnormalities \\
\hline Imaging & Results \\
\hline CT TAP & $\begin{array}{l}\text { Thorax: Entire oesophagus dilated, no lymphadenopathy, fibrotic changes with pleural } \\
\text { thickening and calcification is noted to the right apex. Minimal left pleural effusion. No } \\
\text { evidence of focal lung mass lesion. Abdomen: Scattered diverticulae in the colon, most } \\
\text { numerous in the sigmoid colon wall where there is bowel wall thickening. Liver, } \\
\text { gallbladder, spleen, pancreas, kidneys, adrenals normal. Pelvis: Bladder, uterus and } \\
\text { both adnexa normal. Spondylo-degenerative changes noted to the thoracolumbar } \\
\text { spine with marginal osteophytes and narrow disc heights. No destructive bony lesion } \\
\text { seen. }\end{array}$ \\
\hline MRI lumbosacral spine & $\begin{array}{l}\mathrm{L} 4-\mathrm{L} 5 \text { : Severe medial osteophytosis arising from the left facet joint displacing the } \\
\text { transmitting nerve root, impinging the nerve root on the left lateral recess. } \\
\mathrm{L} 5-\mathrm{S} 2 \text { : Annular bulge with suspicion of the left lateral disc protrusion. Bilateral facet } \\
\text { joint hypertrophy with obliteration of the left lateral recess with impinging at } \mathrm{S} 1, \mathrm{~S} 2 \text {. }\end{array}$ \\
\hline \multicolumn{2}{|c|}{$\begin{array}{l}\text { g/L: grams per litre, ng/L: nanograms per litre, mcg/L: micrograms per litre, /L: per litre, MCV: Mean cell volume, ANCA: Anti- } \\
\text { Neutrophil Cytoplasmic Antibodies, ELISA: Enzyme-Linked Immunosorbent Assay, } \\
\text { Anti-MPO: Anti- Myeloperoxidase, ANA: Anti-nuclear Antibody, ENA: Extractable Nuclear Antibody, FIP1L1-PDGFRA: fusion } \\
\text { gene that causes excess growth of eosinophils, Val617: valine amino acid, JAK2: Janus kinase 2gene, CALR: Calreticulin, CT } \\
\text { TAP: Computed Tomography of Thorax, Abdomen, Pelvis, MRI: Magnetic Resonance Imaging. L: Lumbar, S: Sacral. }\end{array}$} \\
\hline
\end{tabular}


Table 2 trends the response to treatment after patient started prednisolone.

\begin{tabular}{|l|l|l|l|l|}
\hline & Day 1 & $\begin{array}{l}\text { Day 7: (Day before Predni- } \\
\text { solone started) }\end{array}$ & $\begin{array}{l}\text { Day 9: (2 days post } \\
\text { Prednisolone) }\end{array}$ & $\begin{array}{l}\text { Day 18: (8 days post } \\
\text { Prednisolone) }\end{array}$ \\
\hline $\begin{array}{l}\text { Eosinophil count } \\
(0.02-0.5 \times 10 \% / \mathrm{L})\end{array}$ & $\mathbf{1 9 . 9}$ & $\mathbf{2 5 . 1}$ & $\mathbf{5 . 6}$ & $\mathbf{0 . 4}$ \\
\hline
\end{tabular}

Hypereosinophilia was an incidental finding in our patient and this is the case in $6 \%$ of patients according to a retrospective analysis done in $2009^{7}$. Fatigue $(26 \%)$ is usually the most common symptom on presentation ${ }^{1}$. Additionally, the peripheral blood count and bone marrow may also demonstrate basophilia, neutrophilia and mature and immature eosinophils ${ }^{1}$. Some of these findings were also present in our patient. As highlighted previously, sustained eosinophilia increases the risk of damage to virtually all organs. Organ damage occurs because eosinophilic granules contain proteins such as eosinophil peroxidase and eosinophil-derived neurotoxin which are toxic to tissues. Furthermore, eosinophils secrete cytokines that amplify the inflammatory response thus continuing the cycle of tissue damage ${ }^{8}$. Myositis and dilated oesophagus with dysmotility are both documented in the literature as being associated with hypereosinophilia ${ }^{9,10}$. Unfortunately, the patient was too frail to tolerate endoscopy with biopsy, and muscle biopsy of the iliopsoas to provide conclusive evidence of eosinophilic infiltration of these tissues.

Management of IHES requires a multidisciplinary approach dependent on the underlying cause and the presence of complications. The goal of therapy is to prevent or stop the progression of eosinophil-mediated organ damage. 10$20 \%$ of patients with IHES have the FIP1L1PDGFRA fusion gene, which has been identified as a 'therapeutic target of imatinib'1. Therefore, Imatinib is first line/definitive treatment if this gene is present. Otherwise, corticosteroids are first line with hydroxyurea and interferon-alpha being reserved for steroid- refractory cases ${ }^{1}$.

Idiopathic Hypereosinophilic Syndrome is a rare diagnosis of exclusion. If not diagnosed or left untreated, it may result in organ damage. A methodical approach is necessary to arrive at the diagnosis and to guide further management. Another important differential of hyperosinophilia is Eosinophilic Granulomatosis with Polyangiitis (EGPA) which is a vasculitic illness with serious outcomes.

Disclosure statement: The authors report no conflict of interests

Funding: The authors have not received any funding or grants towards the completion of the manuscript.

Author Contributions: JM and NM wrote the article. AM and FW reviewed and corrected the manuscript. AM and FW were the primary senior physicians who managed the patient.

\section{References}

1. Gotlib J. World Health Organization-defined eosinophilic disorders: 2015 update on diagnosis, risk stratification, and management. American Journal of Hematology. 2015;90(11):1077-1089.

2. Roufosse F, Goldman M, Cogan E. Hypereosinophilic syndromes. Orphanet Journal of Rare Diseases. 2007;2(1).

3. UpToDate [Internet]. Uptodate.com. 2019 [cited 28 November 2019]. Available from: https://www.uptodate.com/contents/hypereosinophilic-syndromes-clinical-manifestations-pathophysiology-and-diagnosis

4. Kahn JE, Groh M and Lefèvre G (2017) (A Critical Appraisal of) Classification of Hypereosinophilic Disorders. Front. Med. 4:216.

doi: 10.3389/fmed.2017.00216

5. Eosinophilic granulomatosis with polyangiitis (Churg-Strauss syndrome) - Symptoms, diagnosis and treatment | BMJ Best Practice [Internet]. Bestpractice.bmj.com. 2019 [cited 2 December 2019]. Available from: https://bestpractice.bmj.com/topics/en-us/942

6. Choi C, Park Y, Lee S. Eosinophilic Granulomatosis with Polyangiitis: Experiences in Korean Patients. Yonsei Medical Journal. 2019;60(8):705. 
7. Ogbogu P, Bochner B, Butterfield J, Gleich G, Huss-Marp J, Kahn J et al. Hypereosinophilic syndrome: A multicenter, retrospective analysis of clinical characteristics and response to therapy. Journal of Allergy and Clinical Immunology. 2009;124(6):1319-1325.e3.

8. Acharya KR, Ackerman SJ. Eosinophil granule proteins: form and function. J Biol Chem. 2014 Jun 20;289(25):17406-15.
10.1074/jbc.R113.546218. Epub 2014 May 6. PMID: 24802755; PMCID: PMC4067173.

9. Kaufman L, Kephart G, Seidman R, Buhner D, Qvarfordt I, NäSsberger $L$ et al. The spectrum of eosinophilic myositis. Arthritis \& Rheumatism. 1993;36(7):1014-1024.

10. Spechler S, Konda V, Souza R. Can Eosinophilic Esophagitis Cause Achalasia and Other Esophageal Motility Disorders?. American Journal of Gastroenterology. 2018;113(11):1594-1599.

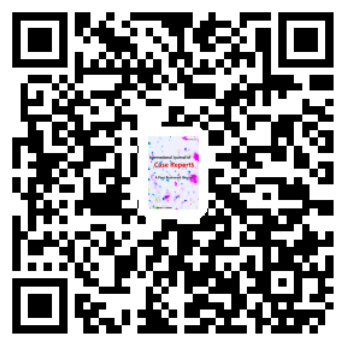

